\title{
PENGEMBANGAN PENYULUHAN URGENSI KESELAMATAN DAN KESEHATAN KERJA (K3) SERTA PELATIHAN PENGGUNAAN ALAT PELINDUNG DIRI (APD) BAGI PERSATUAN TUKANG MANDIRI
}

\section{COUNCELING OF OCCUPATIONAL HEALTH AND SAFETY AND TRAINING OF USING PERSONAL PROTECTIVE EQUIPMENT FOR PERSATUAN TUKANG MANDIRI}

\author{
Oleh: \\ Samsul Bahri ${ }^{1)}$, Besperi ${ }^{1)}$, Rena Misliniyati ${ }^{1)}$, Lisa Martiah Nila Puspita ${ }^{2)}$ \\ ${ }^{1)}$ Dosen Program Studi Teknik Sipil Fakultas Teknik Universitas Bengkulu \\ ${ }^{2)}$ Dosen Jurusan Akuntansi FEB Universitas Bengkulu \\ Email: sbahri1972@yahoo.co.id
}

\begin{abstract}
The most of navvies is the low level education informal worker. More than $80 \%$ of them have only completed their primary school. The navvies are lacking in Occupational Health and Safety (K3). They never wear Personal Protective Equipment (APD) in their activity. Half of them almost do not know about this standard and this equipment. While others say that it is impractical and interfere with their work while they wear it. The purpose of this program is providing information about the urgency of $K 3$ and training in the use of APD for workers. The results of the application of science and technology show that the risk of navvy have the big potential accidents. The program created an awareness of few of them to apply $K 3$ although not yet fully implemented. K3 is very important and useful for navvy.
\end{abstract}

Keywords: safety, health, work, navvy, accidents

\section{PENDAHULUAN}

President Institution of Occupational Safety and Health (IOSH), Gerard Hand, di Jakarta, pada Selasa (8/10/13) menyampaikan bahwa menurut data Internasional Labor Organization (ILO), rata-rata per tahun terdapat 99.000 kasus kecelakaan kerja di Indonesia. Dari total jumlah itu, sekitar 70 persen berakibat fatal yaitu kematian dan cacat seumur hidup. Menurut Gerard, untuk mengurangi kecelakaan kerja harus meningkatkan pengetahuan dalam bidang keselamatan dan kesehatan kerja (K3). Ia menegaskan, pengetahuan dan kecakapan para majikan sangat penting untuk memastikan kesehatan dan keselamatan para pekerja, sebagai yang paling utama dan tidak dapat ditawar-tawar. "Hal ini tidak saja menyelamatkan nyawa manusia, tetapi juga menjadikan bisnis lebih efisien," kata dia. "Kita harus bekerjasama untuk memastikan bahwa keselamatan dan kesehatan kerja yang baik dan realistis menjadi hak yang paling mendasar bagi seluruh pekerja di Indonesia," ungkapnya (suarapembaruan.com, Rabu, 9 Oktober 2013). 
Rinaldi (2013) mengutarakan bahwa industri jasa konstruksi menduduki peringkat pertama dalam jumlah kecelakaan meninggal. Bahkan angka kecelakaan kerja sektor konstruksi di Indonesia termasuk yang paling tinggi di kawasan ASEAN dan dalam lima tahun terakhir trennya cenderung naik. Kepala Badan Pembinaan (BP) Konstruksi Kementerian Pekerjaan Umum, Hediyanto Husaini mengungkapkan ada berbagai penyebab utama kecelakaan kerja di sektor konstruksi antara lain berkaitan dengan karakteristik proyek konstruksi yang bersifat unik, lokasi kerja yang berbeda-beda, banyak menggunakan tenaga kerja yang tidak terlatih, serta manajemen keselamatan kerja yang sangat lemah.

Kelompok tukang yang tergabung dalam Persatuan Tukang Mandiri merupakan salah satu kelompok tukang diantara sekian banyak kelompok-kelompok tukang yang banyak digunakan jasanya dalam pembangunan proyek-proyek di Provinsi Bengkulu. Kelompok Persatuan Tukang Mandiri adalah pekerja musiman/tidak tetap dengan tingkat pendidikan formal yang rendah, karena lebih dari $80 \%$ hanya tamat SD. Persatuan Tukang Mandiri adalah para pekerja yang ulet, terampil, tekun dan relatif mudah untuk diarahkan dalam bekerja. Mereka sangat kompak dan rukun sehingga banyak kontraktor yang mempekerjakannya baik dengan sistem upah borongan maupun harian.

Sayangnya, para tukang ini sangat kurang dalam menjaga keselamatan dan kesehatan kerja (K3). Bisa dikatakan mereka tidak pernah memakai Alat Pelindung Diri (APD) dalam melakukan aktivitas pertukangannya. Ketika ditanyakan mengapa mereka tidak berupaya menjaga K3 dengan cara menggunakan APD, sebagian besar menjawab tidak tahu. Sementara yang lainnya mengatakan penggunaan APD tidak praktis dan gerakan kerja menjadi terhambat kalau harus memakai APD.

Untuk itu perlu dilakukan penerapan ipteks dengan tujuan memberikan penyuluhan tentang urgensi Keselamatan dan Kesehatan Kerja dan memberikan pelatihan penggunaan Alat Pelindung Diri (APD) dalam bekerja.

Pengelolaan proyek yang baik, akan memperhatikan K3, sebagai upaya meminimalisir setiap potensi timbulnya kecelakaan kerja yang melibatkan tenaga tukang. Rendahnya pendidikan dan tingkat pengetahuan para tukang, bukan menjadi kendala utama dalam penerapan K3. Dari analisis yang dilakukan, maka masalah yang timbul adalah bagaimana mengubah rendahnya tingkat pengetahuan dan keengganan kelompok Persatuan Tukang Mandiri dalam penerapan K3, menjadi faham dan secara bertahap berkenan menerapkan K3 dan menggunakan APD tanpa harus merasa direpotkan.

\section{Pengertian Keamanan dan Keselamatan Kerja}

Menurut Undang-undang Nomor 18 Tahun 1999 tentang Jasa Konstruksi, asas keamanan dan Keselamatan mengandung pengertian terpenuhinya tertib penyelenggaraan jasa konstruksi, keamanan lingkungan dan keselamatan kerja, serta memanfaatan hasil pekerjaan konstruksi dengan tetap memperhatikan kepentingan umum. Levitt dan Samelton (1993) menyatakan bahwa keselamatan konstruksi adalah usaha untuk meniadakan dari resiko kerugian/luka-luka dari suatu kecelakaan dan kerusakan kesehatan 
yang diakibatkan oleh efek jangka pendek maupun jangka panjang akibat dari lingkungan kerja tak sehat.

Tang (2004) melaporkan angka kematian akibat kecelakaan kerja pada sektor konstruksi adalah 40 per 100.000 pekerja dan 32\% dari seluruh kecelakaan. Padahal jumlah pekerja di sektor konstruksi hanya 5\% dari seluruh pekerja. Kecelakaan konstruksi menimbulkan kerugian finansial, kerugian kemanusiaan, dan kerugian sosial.

Keselamatan juga merupakan bagian dari etika profesi bagi orang-orang yang terlibat dalam pengembangan teknologi (Vesilind, 2001). Dari aspek tenaga kerja, kebutuhan keselamatan adalah kebutuhan manusia (dalam hal ini pekerja), setelah kebutuhan primer terpenuhi (Andi, 2004; Uwakweh, 2004).

\section{Penyebab Kecelakaan Konstruksi}

Chua dan Goh (2004) membagi kecelakaan dalam tiga kategori, yaitu: (a) Kategori pemindahan tenaga (energy transfer), memusatkan perhatian pada transmisi energi berturut-turut dari sumber energi, penghalang (antara korban dan sumber energi), dan korban. (b) Kategori individual, yang memusatkan perhatian kepada individu sebagai penyebab langsung kecelakaan. (c) Kategori sistemik, yang memusatkan perhatian kepada peranan organisasi dan sistem dalam meninjau penyebab kecelakaan.

Perencanaan keselamatan pra-konstruksi perlu dibuat secara komprehensif, integratif dan sisitematis. Perencanaan keselamatan pra-konstruksi dinilai kematangannya sebelum dilanjutkan ke tahap pelaksanaan (Endroyo et al, 2009).

\section{Regulasi Keselamatan Dan Kesehatan Kerja}

Peraturan Menteri Tenaga Kerja dan Transmigrasi No 01 Tahun 1980 Tentang Keselamatan dan Kesehatan Kerja pada Konstruksi Bangunan mengamanatkan tentang beberapa hal sebagai berikut:

Pasal 3 menyatakan bahwa (1) pada setiap pekerjaan konstruksi bangunan harus diusahakan pencegahan atau dikurangi terjadinya kecelakaan atau sakit akibat kerja terhadap tenaga kerjanya. (2) Sewaktu pekerjaan dimulai harus segera disusun suatu unit keselamatan dan kesehatan kerja, hal tersebut harus diberitahukan kepada setiap tenaga kerja. (3) Unit keselamatan dan kesehatan kerja tersebut ayat (2) pasal ini meliputi usahausaha pencegahan terhadap: kecelakaan, kebakaran, peledakan, penyakit akibat kerja, pertolongan pertama pada kecelakaan dan usaha-usaha penyelamatan.

\section{Komponen $\mathrm{K3}$}

Berdasarkan Peraturan Menteri Tenaga Kerja dan Transmigrasi Nomor Per.08/Men/VII/2010 Tentang Alat Pelindung Diri; APD setidak-tidaknya meliputi: pakaian kerja, sepatu kerja, helm, kacamata kerja, sabuk pengaman, sarung tangan, penutup telinga, masker, tangga dan $\mathrm{P} 3 \mathrm{~K}$. 
Tujuan dari penerapan ipteks pada kelompok Persatuan Tukang Mandiri adalah sebagai berikut memberikan penyuluhan tentang urgensi Keselamatan dan Kesehatan Kerja. Memberikan pelatihan penggunaan Alat Pelindung Diri (APD) dalam bekerja.

Sedangkan manfaat yang akan didapatkan dari kegiatan penerapan ipteks adalah Kelompok Persatuan Tukang Mandiri akan mengetahui, memahami dan menyadari akan pentingnya menjaga Keselamatan dan Kesehatan Kerja. Kelompok Persatuan Tukang Mandiri mengetahui, mengenal dan mau menggunakan Alat Pelindung Diri (APD) saat bekerja. Lembaga Penelitian dan Pengabdian pada Masyarakat UNIB akan lebih dikenal kiprah dan kontribusinya ditengah masyarakat.

\section{METODE PENGABDIAN}

\section{Pemilihan Mitra}

Bekerja pada sektor konstruksi/bangunan adalah jenis pekerjaan dengan resiko sangat tinggi apabila terjadi kecelakaan. Rendahnya pendidikan dan tingkat pengetahuan serta kecerobohan para tukang saat bekerja, menjadi faktor utama timbulnya kecelakaan dalam bekerja.

Dari identifikasi terhadap beberapa kelompok tukang, terpilih kelompok Kelompok Persatuan Tukang Mandiri Kelurahan Bentiring Permai. Dipilihnya kelompok Persatuan Tukang Mandiri sebagai khalayak sasaran kegiatan penerapan ipteks ini karena kelompok ini memiliki organisasi yang baik, ada ketua yang memiliki pengaruh kuat dan lebih dari 20 anggota aktif. Harapan kedepan kelompok ini mampu menyebarluaskan hasil kegiatan dan menjadi contoh bagi kelompok tukang yang lainnya dalam penerapan K3 dan APD.

\section{Bahan dan Alat yang Digunakan}

Untuk kegiatan penyuluhan Keselamatan dan Kesehatan Kerja (K3) diperlukan alat peraturan-peraturan pengelolaan $\mathrm{K} 3$ yang disarikan dalam bentuk powerpoint. Alat bantu untuk presentasi digunakan laptop, lcd dan peralatan pendukung lainnya. Pelatihan penggunaan Alat Pelindung Diri (APD) dalam bekerja menggunakan alat peraga helm, sepatu kerja, kaca mata kerja, masker, dan lain-lain.

\section{Metode Penerapan Ipteks}

Untuk menyelesaikan permasalahan yang telah dirumuskan, berikut diuraikan metode penerapan ipteks bagi kelompok Persatuan Tukang Mandiri.

1. Penyuluhan Keselamatan dan Kesehatan Kerja (K3).

Dalam tahap ini, para peserta diberikan penyuluhan berkenaan dengan:

a. Definisi keselamatan dan kesehatan kerja.

b. Dasar hukum penerapan K3 di tempat kerja.

c. Tujuan penerapan K3.

d. Pengertian bahaya dan faktor-faktor bahaya di tempat kerja.

e. Pengertian resiko dan penilaian resiko K3. 
f. Hierarki pengendalian bahaya K3.

g. Pengertian kecelakaan kerja dan insiden kerja.

h. Sebab-sebab kecelakaan kerja.

i. Kerugian kecelakaan kerja

j. Piramida kecelakaan kerja.

k. Upaya pencegahan kecelakaan kerja.

1. Penyakit akibat kerja.

m. Kewajiban tenaga kerja terhadap penerapan K3.

2. Pelatihan penggunaan Alat Pelindung Diri (APD).

Pada tahap ini, para peserta akan dikenalkan: jenis-jenis APD, fungsi APD, persyaratan APD, cara penggunaan APD dan manfaat APD.

3. Diskusi tentang materi yang telah disampaikan.

4. Demonstrasi penggunaan APD.

\section{Cara Pengumpulan dan Interpretasi Data}

Proses penyadaran penerapan K3 dan penggunaan APD oleh para tukang membutuhkan waktu yang relarif lama. Kondisi ini dilatarbelakangi oleh tingkat pendidikan dan budaya kerja yang kurang baik. Untuk itu perlu pemantauan secara kontinyu dengan pendekatan kekeluargaan.

\section{HASIL DAN PEMBAHASAN}

\section{Penyuluhan K3}

\section{Regulasi Pelaksanaan K3}

Dalam kegiatan penyuluhan $\mathrm{K} 3$, para peserta dikenalkan dengan peraturan dan perundangan yang berkaitan dengan Kesehatan dan Keselamatan Kerja (K3) pada pekerjaan konstruksi. Peraturan dan perundangan yang terkait diantaranya adalah:

1. Bangsa Indonesia sebagai bangsa-bangsa didunia, telah turut serta dalam Konvensi Internasional tentang perlindungan terhadap tenaga kerja.

2. Pada tahun 1989 telah dikeluarkan Undang-undang No.14 tahun 1989 tentang KesehatanTenaga Kerja, sebagai pengganti Undang-undang No.1 tahun 1970 tentang Keselamatan Kerja.

3. Pada tahun 1980 Menteri Tenaga Kerja telah mengeluarkan Peraturan No.01/MEN/1980 tentang Keselamatan dan Kesehatan Kerja pada Konstruksi Bangunan.

4. Pada tahun 1986 Menteri Pekerjaan Umum dan Menteri Tenaga Kerja menerbitkan Surat Keputusan bersama No.174/MEN/1986 dan 104/KPTS/1986 tentang Pedoman Kesehatan dan Keselamatan Kerja pada Tempat Pekerjaan Konstruksi.

Pada Gambar 1 menjelaskan tentang hirarkis organisasi kesehatan dan keselamata kerja di Indonesia menyangkut peraturan perundangan dan stokeholders yang 
berkepentingan dalam K3. Nampak bahwa para pekerja konstruksi/tukang sangat dilindungi dan dijamin kesehatan dan keselamatan selama bekerja, mengingat SDM tukang memegang peran penting dalam kesuksesan seuatu proyek konstruksi.

\section{Dampak Bila Tidak Melaksanakan K3}

Kesehatan dan Keselamatan Kerja (K3) sangat penting dan bermanfaat baik bagi pemberi kerja, pemborong maupun tenaga kerja. Bila tidak melaksanakannya dapat menimbulkan kerugian. Kerugian-kerugian antara lain:

1. Bagi Pemberi Kerja

Bila terjadi kecelakaan dan terjadi musibah (misalnya kebakaran), maka proyek dapat tertunda penyelesaiannya. Sekalipun pemberi kerja tidak akan mengeluarkan biaya tambahan karena adanya kebakaran tsb, namun tertundanya penyelesaian proyek bearti merupakan penundaan manfaat proyek yang dibiayai dari dana kredit, jelas pemberi kerja akan menanggung bunga kredit itu selama waktu tertundanya proyek beroperasi.

2. Bagi Kontraktor

Banyak sekali kerugian yang harus dipikul. Baik kerugian dalam keuangan, beban pikiran dan reputasi. Bila terjadi kecelakaan dan kecelakaan tersebut menimbulkan kerugian masyarakat yang besar, kontraktor akan diprotes, dituntut bahkan dicacimaki oleh Pers.

3. Bagi Tenaga Kerja (Naker)

Bagi tenaga kerja yang mendapat kecelakaan, apalagi cacat berat bearti yang bersangkutan akan kehilangan kesempatan bekerja sesuai kemampuan yang dimilikinya, atau tidak dapat bekerja sama sekali. Bagi yang sudah berumahtangga kecelakaan dapat menimbulkan penderitaan istri dan anak-anaknya. 


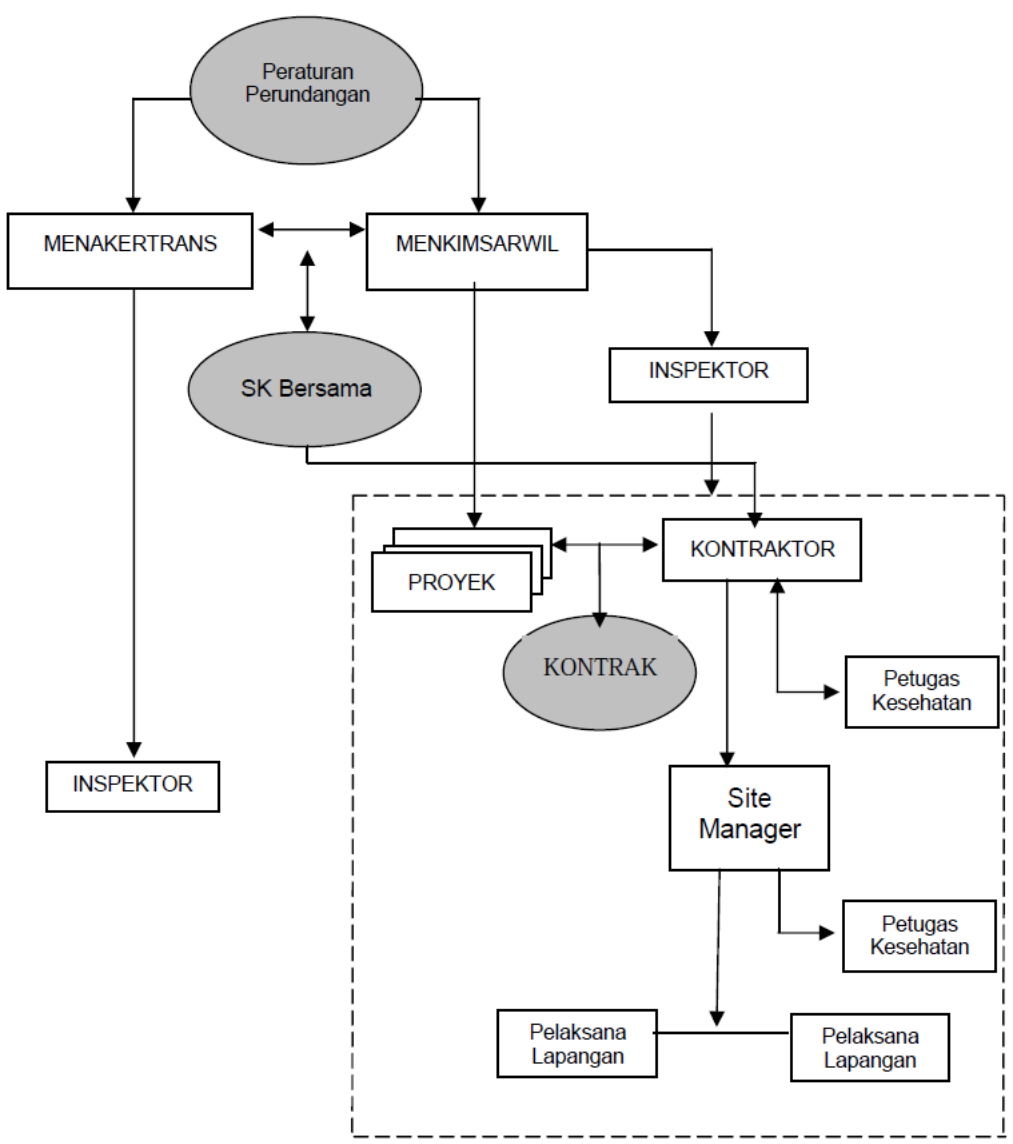

Gambar 1 Organisasi Kesehatan dan Keselamatan Kerja

\section{Kecelakaan Pada Pekerjaan Konstruksi}

Pekerjaan konstruksi tergolong pekerjaan yang mengandung atau mempunyai potensi terjadinya kecelakaan yang cukup besar. Kecelakaan pada pekerjaan konstruksi bermacam-macam. Ada kecelakaan akibat terkena benda jatuh atau yang disebabkan karena terpukul, benda tajam, sengatan aliran listrik, tergelincir dll.

Data statistik kecelakaan pada pekerjaan konstruksi di Indonesia diperlihatkan pada Tabel 1 sebagai berikut:

Tabel 1 Data Statistik Kecelakaan di Indonesia

\begin{tabular}{|c|c|c|}
\hline Kriteria & Prosentase & Sebab-sebab kecelakaan \\
\hline & $30 \%$ & Pengangkutan dan lalu-lintas \\
\hline & $29 \%$ & Kejatuhan benda \\
\hline & $5 \%$ & Kebakaran \\
\hline
\end{tabular}

Sumber: http://www.suarapembaruan.com, 9 Oktober 2013 


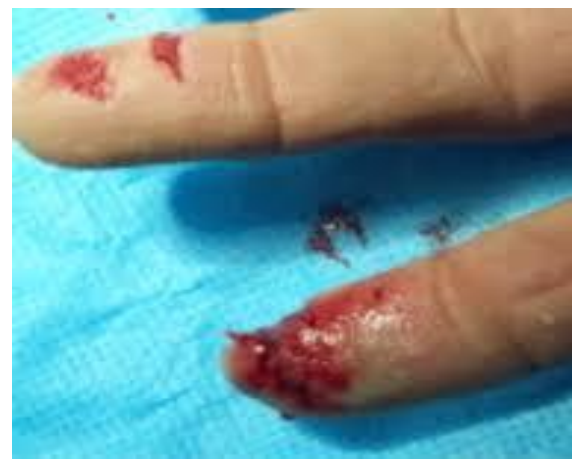

a. Jari Terpotong

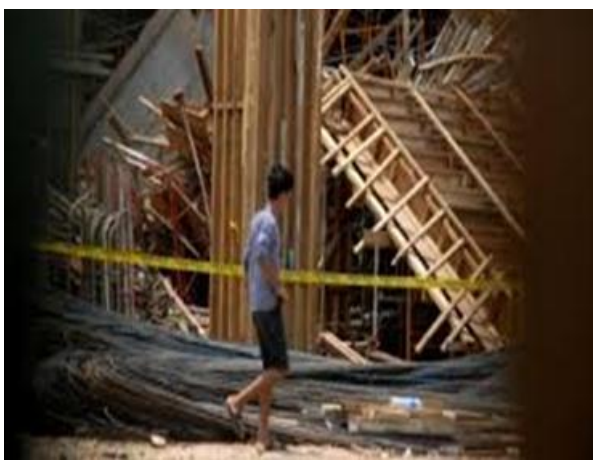

b. Konstruksi Roboh

Gambar 2. Kecelakaan Faktor Manusia dan Konstruksi

\section{Sebab Sebab Kecelakaan}

Sebab-sebab terjadinya kecelakaan digolongkan dalam dua kelompok yaitu yang disebabkan faktor manusia dan faktor konstruksi (alat dan lingkungan). Bahaya kecelakaan kerja oleh manusia disebabkan oleh kurangnya pengertian, kurang pengetahuan, kurang disiplin, kondisi mental misalnya emosi, kejenuhan dan sebaginya. Bahaya kecelakaan kerja yang disebabkan oleh faktor konstruksi antara lain tidak adanya perencanaan $\mathrm{K} 3$, minimnya pengamanan, pengoperasian alat tidak sesuai, konstruksi salah sehingga roboh. Keadaan lingkungan yang kurang baik misalnya lapangan atau tempat kerja licin, gelap, pengap, berdebu dan lain-lain.

Gambar 2.a adalah contoh kecelakaan yang diakibatkan oleh kelalaian tukang dalam bekerja yang berakibat pada terpotongnya ujung jari tangan ketika bekerja. Hal ini disebabkan karena tidak menggunakan sarung tangan dan tidak hati-hati ketika bekerja. Sedangkan Gambar 2.b adalah contoh kecelakaan konstruksi akibat kurang terkontrolnya pemasangan begisting/perancah untuk penompang struktur balok dan plat beton. Kondisi ini sangat berbahaya karena sangat membahayakan keselamatan manusia dan konstruksi itu sendiri.

\section{Upaya Pencegahan Kecelakaan}

Pencegahan kecelakaan yang disebabkan oleh faktor manusia dapat ditempuh berbagai upaya antara lain:

1. Kampanye dan penyuluhan Kesehatan dan Keselamatan Kerja (K3) secara berkala untuk menumbuhkan kesadaran ber -K3.

2. Mengadakan latihan dan demontrasi Kesehatan dan Keselamatan Kerja (K3) bagi para pekerja maupun staff kontraktor misalnya: latihan eveluasi bahaya kebakaran, caracara P3K dsb.

3. Melakukan pengecekan secara teratur terhadap alat-alat Kesehatan dan Keselamatan Kerja (K3), peralatan P3K, alarm/sirine tanda kebakaran dsb.

4. Memasang poster dan tanda-tanda Kesehatan dan Keselamatan Kerja (K3) ditempat strategis. 
5. Memberikan sanksi bagi pekerja yang melanggar peraturan Kesehatan dan Keselamatan Kerja (K3) dan memberikan penghargaan bagi pekerja yang telah patuh dan melaksanakan Kesehatan dan Keselamatan Kerja (K3).

6. Mengadakan pertemuan, dialog atau diskusi khusus tentang Kesehatan dan Keselamatan Kerja (K3) bagi seluruh karyawan.

7. Penelitian bersifat teknis, Penelitian medis, dan Penelitian psikologis

8. Standarisasi alat dan perlengkapan kerja

9. Pengawasan bersifat umum dan khusus

10. Asuransi kecelakaan

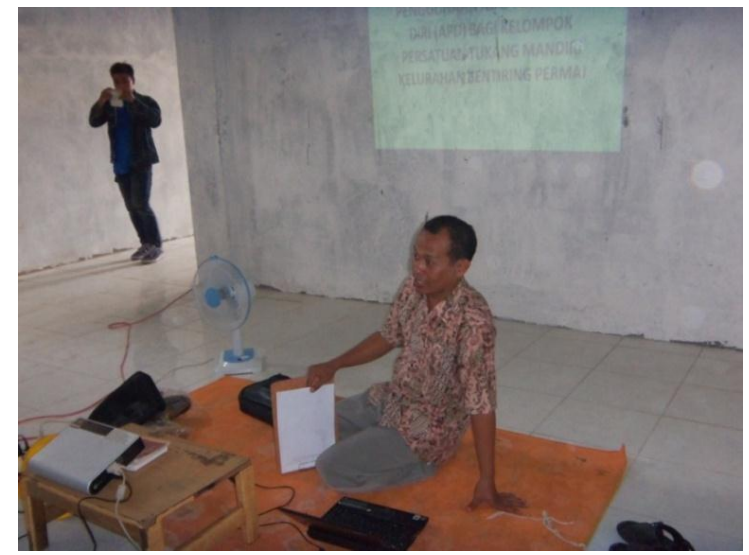

Gambar 3. Kegiatan Penyuluhan K3

Gambar 3 adalah kegiatan penyuluhan Keselamatan dan Kesehatan Kerja yang dilakukan oleh tim pengabdian sebagai bagian dari kampanye K3 untuk mencegah kecelakaan kerja dikalangan Persatuan Tukang Mandiri. Kegiatan ini merupakan bentuk kepekaan sosial terhadap khalayak sararan dengan cara penyuluhan K3 agar nantinya para tukang lebih berhati-hati, taat prosedur dan senantiasa mengindahkan dan melaksanakan K3 bagi diri mereka sendiri.

\section{Pelatihan Penggunaan Alat Pelindung Diri (APD)}

Dalam pelaksanaan pelatihan penggunaan Alat Pelindung Diri, para tukang dikenal jenis dan fungsi serta praktek penggunaan dari APD untuk tiap unit APD dimaksud. Berikut APD yang disampaikan dalam penerapan ipteks: 


\section{Pakaian Kerja}

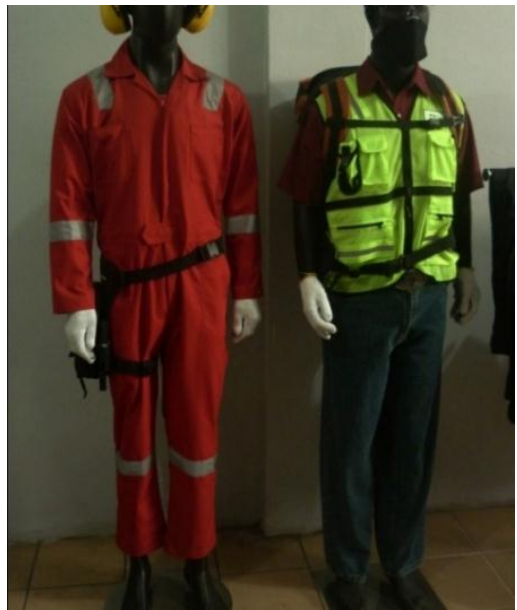

Sumber: symponiapromo.com

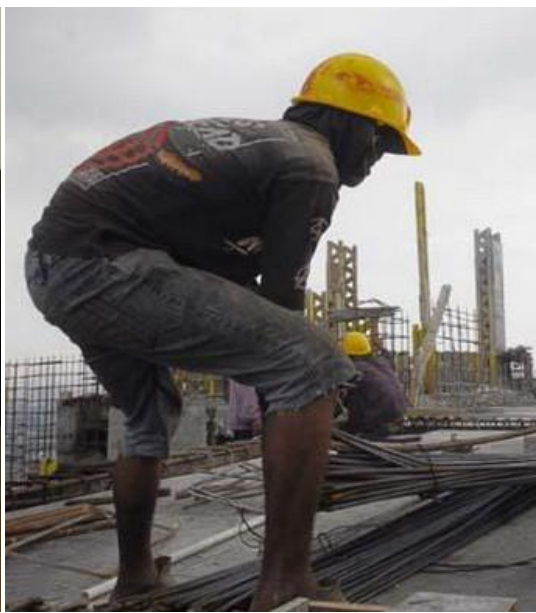

Sumber: tulisandrmuda.blogspot.com

Gambar 4. Contoh Penggunaan Pakaian Kerja Standar vs Tidak Standar

Tujuan penggunaan pakaian kerja adalah melindungi seluruh anggota tubuh manusia terhadap pengaruh-pengaruh yang kurang sehat atau yang bisa melukai. Gambar 4 adalah contoh penggunaan pakaian kerja dari bahan yang standar dan tidak standar.

\section{Sepatu Kerja}

Sepatu kerja (safety shoes) merupakan perlindungan terhadap kaki. Setiap pekerja konstruksi perlu memakai sepatu dengan sol yang tebal supaya bisa bebas berjalan dimanamana tanpa terluka oleh benda-benda tajam atau kemasukan oleh kotoran dari bagian bawah. Bagian muka sepatu harus cukup keras supaya kaki tidak terluka kalau tertimpa benda dari atas.

\section{Kacamata Kerja}

Kacamata pengaman digunakan untuk melidungi mata dari debu kayu, batu, atau serpihan besi yang beterbangan di tiup angin. Oleh karenanya mata perlu diberikan perlindungan. Biasanya pekerjaan yang membutuhkan kacamata adalah mengelas.

\section{Sarung Tangan}

Tujuan utama penggunaan sarung tangan adalah melindungi tangan dari bendabenda keras dan tajam selama menjalankan kegiatannya. Salah satu kegiatan yang memerlukan sarung tangan adalah mengangkat besi tulangan, kayu. Pekerjaan yang sifatnya berulang seperti mendorong gerobag cor secara terus-menerus dapat mengakibatkan lecet pada tangan yang bersentuhan dengan besi pada gerobag.

\section{Helm}

Helm (helmet) sangat penting digunakan sebagai pelindug kepala, dan sudah merupakan keharusan bagi setiap pekerja konstruksi untuk mengunakannya dengar benar sesuai peraturan. Helm ini digunakan untuk melindungi kepala dari bahaya yang berasal 
dari atas, misalnya saja ada barang, baik peralatan atau material konstruksi yang jatuh dari atas. Memang, sering kita lihat kedisiplinan para pekerja untuk menggunakannya masih rendah yang tentunya dapat membahayakan diri sendiri. Gambar 5 adalah demonstrasi penggunaan helm standar yang harus digunakan oleh tukang ketika bekerja.

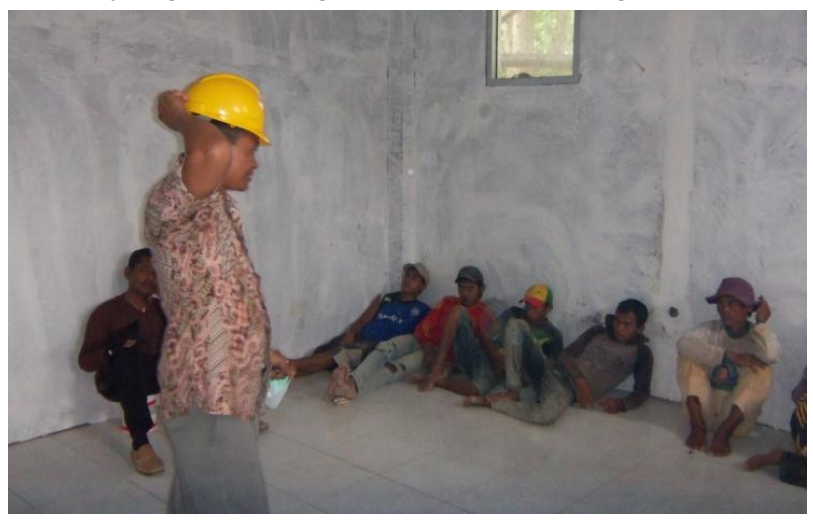

Gambar 5. Demonstrasi Penggunaan Helm Standar

\section{Sabuk Pengaman}

Fungsi utama tali pengaman ini adalah menjaga seorang pekerja dari kecelakaan kerja, misalnya saja kegiatan erection baja pada bangunan tower atau bangunan dengan ketinggian tertentu.

Masker

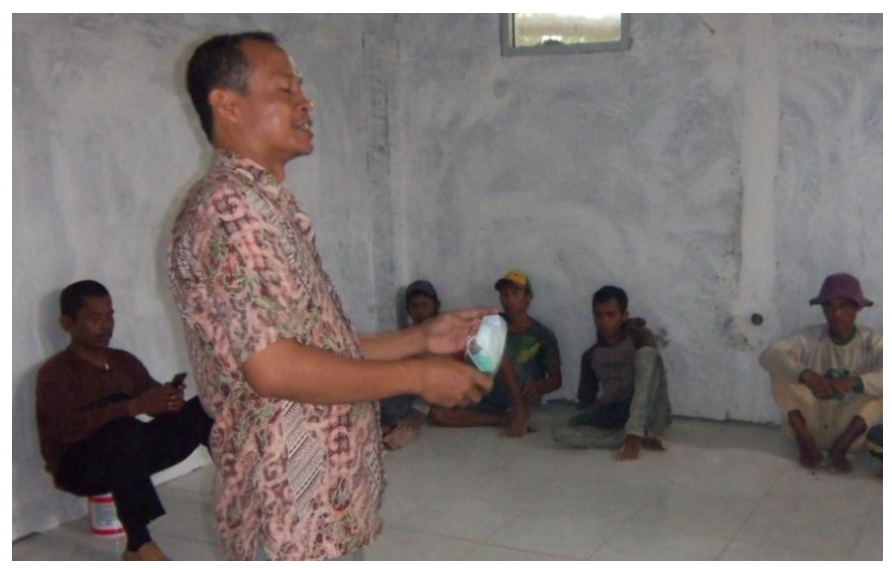

Gambar 6. Penjelasan Tentang Masker

Pelindung bagi pernapasan sangat diperlukan untuk pekerja konstruksi mengingat kondisi lokasi proyek itu sediri. Berbagai material konstruksi berukuran besar sampai sangat kecil yang merupakan sisa dari suatu kegiatan, misalnya serbuk kayu sisa dari kegiatan memotong, mengampelas, mengerut kayu. Gambar 6 adalah penjelasan mengenai fungsi, manfaat dan praktek menggunakan masker saat bekerja. 
P3K

Apabila terjadi kecelakaan kerja baik yang bersifat ringan ataupun berat pada pekerja konstruksi, sudah seharusnya dilakukan pertolongan pertama di proyek. Untuk itu perlu disediakan obat-obatan yang digunakan untuk pertolongan pertama pada korban kecelakaan kerja.

\section{Dampak Kegiatan}

Setelah kegiatan penerapan PPM Ipteks ini selesai dilaksanakan, beberapa tukang sudah mulai menerapkan K3 walaupun belum sepenuhnya terlaksana. Gambar 7 berikut menyajikan kondisi tukang yang bekerja tanpa alat kaki. Sedangkan Gambar 8 adalah gambaran tukang yang sudah penggunakan alat perlengkapan diri berupa sepatu kerja.

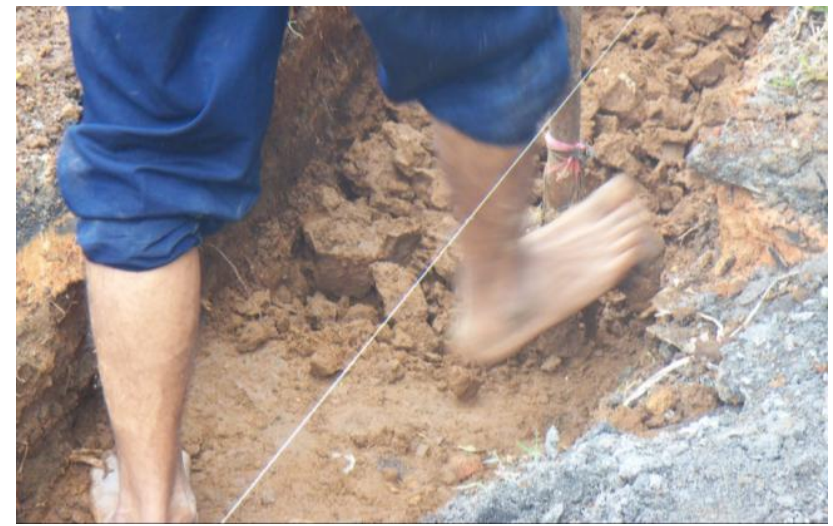

Gambar 7. Tukang Bekerja Menggali Tanah Tanpa Alas Kaki

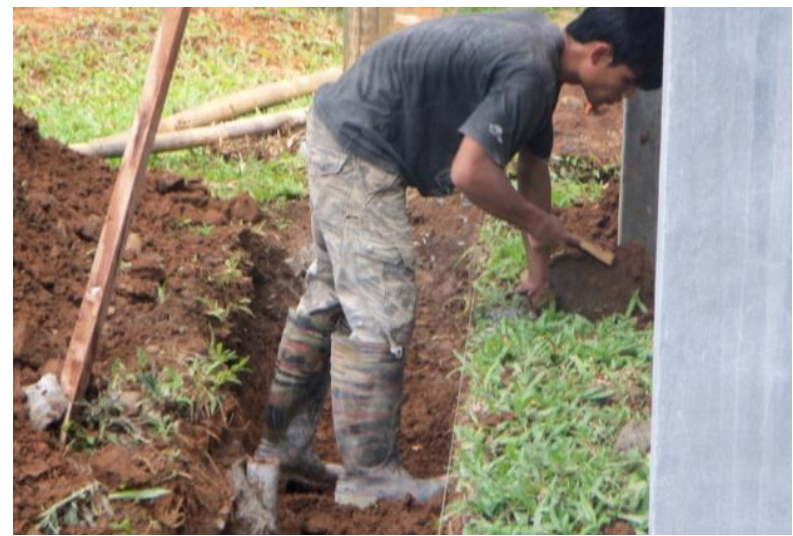

Gambar 8. Tukang Bekerja Menggali Tanah dengan Menggunakan Sepatu Kerja

\section{KESIMPULAN DAN SARAN}

\section{Kesimpulan}

Kesimpulan dari penerapan ipteks yang telah dilaksanakan adalah sebagai berikut:

1. Kesehatan dan Keselamatan Kerja (K3) sangat penting dan bermanfaat baik bagi pemberi kerja, pemborong maupun tenaga kerja.

2. Pekerjaan konstruksi tergolong pekerjaan yang mempunyai potensi terjadinya kecelakaan yang cukup besar. 
3. Alat Pelindung Diri (APD) meliputi pakaian kerja, sepatu kerja, helm, sarung tangan, kaca mata kerja, sabuk pengaman dan P3K yang harus digunakan saat tukang bekerja sesuai dengan jenis pekerjaan yang sedang dilaksanakan.

4. Setelah kegiatan penerapan ipteks ini selesai dilaksanakan, beberapa tukang sudah mulai menerapkan K3 walaupun belum sepenuhnya terlaksana.

\section{Saran}

Bekerja disektor konstruksi memiliki resiko kecelakaan yang tinggi. Untuk itu pihak terkait seperti pemberi kerja, pemborong dan tukang harus menerapkan Kesehatan dan Keselamatan Kerja (K3) dan senantiasa menggunakan Alat Pelindung Diri (APD) dengan disiplin.

\section{DAFTAR PUSTAKA}

Andi, 2004, Motivation Perception of Construction Workers and Their Supervisors in Indonesia, Proccedings of International Symposium on Globalitation and Construction, Thailand.

Chua, D.K.H., and Goh, Y.M., 2004, Incident Causation Model for Improving Feedback of Safety Knowledge, Journal of Construction Engineering and Management, July/Aug 2004.

Endroyo, B., Yuwono, B.E., dan Kartono, 2009, Studi Tentang Model Penilaian Kematangan Perencanaan Keselamatan pada Tahap Prakonstruksi untuk Mitigasi Kecelakaan Konstruksi, Artikel, Jurusan Sipil Fakultas Teknik Universitas Negeri Semarang.

Levitt, R.E., and Samelton, N.M., 1993, Construction Safety Management, New York: John Wiley \& Sons, Inc.

Peraturan Menteri Tenaga Kerja dan Transmigrasi No 01 Tahun 1980 Tentang Keselamatan dan Kesehatan Kerja pada Konstruksi Bangunan, Jakarta 06 Maret 1980.

Peraturan Menteri Tenaga Kerja dan Transmigrasi Nomor Per.08/Men/VII/2010 Tentang Alat Pelindung Diri, Jakarta: Berita Negara Republik Indonesia Tahun 2010 NOMOR 330.

Rinaldi, M., 2013, Kecelakaan Kerja Sektor Konstruksi Tertinggi di ASEAN, http://www.indonesiafinancetoday.com, 26 Agustus 2013.

Tang, S.L., 2004, Costs of Construction Accidents in Sosial and Humannity Context, The Ninth East Asia Pacific Conference on Structural Engineering and Construction 2004.

Undang-undang No. 18 Tahun 1999 Tentang Jasa Konstruksi, Jakarta: Lembaran Negara Republik Indonesia Tahun 1999 Nomor 54. 
Vesilind, 2001, Engineering as Applied Social Science, Journal of Professional Issues in Engineering Education and Practice Volume 127 No. 4 Oct 2001.

Uwakweh, B.O., 2004, Motivating Craft Workers: A Case Study with Nigerian Workers, Proccedings of International Symposium on Globalitation and Construction, Thailand.

http://www.suarapembaruan.com, Ancaman Kecelakaan Kerja di Indonesia Masih Tinggi, 9 Oktober 2013. 